\title{
Arte e Literatura
}





\title{
Elucubrações dramáticas do professor Oiticica
}

\author{
ANTONIO ARNONI PRADO
}

A PRESENÇA de José Oiticica (1882-1957) no movimento anarquista brasileiro, a exemplo de sua personalidade e de sua obra intelectual, é ainda hoje um tema cercado de opiniões controversas. Alguns cronistas que o conheceram de perto, impressionados com a personalidade do homem e do mestre que ele foi, não hesitam em comparar o seu legado ao dos grandes sábios, não sendo raros os que, bem medido o despropósito, vão ao ponto de incluí-lo na categoria dos gênios, tão forte é a impressão que lhes ficou da variedade e da amplitude de seus conhecimentos. "Foi um dos maiores sábios que conheci na minha vida" - afirma o professor Cândido Jucá Filho, que em certa época conviveu de perto com Oiticica. "Eram-lhe familiares as humanidades, conhecia história, filosofia e filologia como poucos, entendia-se em matemática e em medicina. Em línguas, não somente cultivou com escrúpulo o português, como ainda ensinou, além dessa, o francês, o latim e o grego. Sabia o alemão, que praticou em Hamburgo, quando por lá demorou; e ultimamente incursionara pelo russo. Lia muitos outros idiomas" (1). Da mesma opinião é o ensaísta Roberto das Neves, no texto com que abre a seleção, que organizou para a editora Germinal, de artigos publicados por José Oiticica na folha libertária $A c ̧ \tilde{a} o$ Direta, do Rio de Janeiro: um sábio, um poliglota, "o primeiro poeta no Brasil a compor poemas originais em esperanto", um homem, a seu ver, capaz de discorrer "com segurança e profundamente" sobre artes plásticas, música, teatro, matemática, física, química, filosofia, medicina, psicologia, história, sociologia, economia etc. (2).

Tais juízos tendem ainda a ampliar-se quando ingressamos na crônica ardorosa das façanhas do nosso autor, entre as quais a da célebre conquista da cátedra do colégio Pedro II, de que hoje temos notícias graças ao relato, narrado por Teófilo de Andrade, de um episódio que ouvira do amigo Ildefonso Falcão (3). Chegado havia pouco ao Rio de Janeiro, o jovem Oiticica - nas palavras de Teófilo - "temia ser levado de vencida pelas contingências da política escolar, sobretudo porque a sua tese era apenas a demonstração dos erros contidos nos livros dos que o iam examinar. Prevendo a tempestade, convidou para assistir às provas a Carlos Maximiniano, 
ministro da Justiça de Venceslau Brás, a quem estavam, naquela época, afetas as questões do ensino". Não é preciso dizer que o concurso se transformou numa batalha memorável ante os olhos do ministro, embasbacado com o talento daquele "pequeno David armado tão somente com a funda da sua competência". Nomeado por Carlos Maximiniano, conclui Teófilo de Andrade, "o que Oiticica ensinou aos examinadores, no concurso, ficou ensinando durante décadas nas cátedras que freqüentou" (4).

“O professor José Oiticica era o professor José Oiticica. Não se parecia com pessoa alguma deste mundo", disse dele o acadêmico Viriato Corrêa num dos discursos da sessão de homenagem promovida pela Academia Brasileira de Letras por ocasião de sua morte, em junho de 1957. "Pensava a seu modo, agia ao seu modo" - prossegue Corrêia. "As suas opiniões só ele as tinha, os seus gostos eram dele unicamente. E de sua maneira de ser não se afastava um milímetro, mesmo que tivesse de ir parar à cadeia. E muitas vezes o foi, mas a cadeia nunca teve poder para lhe apagar a bravura do pensamento e das atitudes" (5). Corrêa aludia aqui à outra face que viria completar a efígie do homem culto e erudito: a face subversiva do intelectual combativo, que compunha com a imagem serena do mestre compenetrado uma espécie de retrato maldito à semelhança do médico e do monstro, a partir do qual Oiticica seria reconhecido para o resto da vida, mais ou menos como se o educador disciplinado e incansável que ele era de dia se convertesse, à noite, num carbonário destemido a tramar contra a ordem estabelecida, como de fato acontecera por ocasião da greve geral de 1918 no Rio de Janeiro, que redundou na tentativa frustrada de assalto ao palácio do governo.

É bom no entanto assinalar que também aqui as opiniões não coincidem. O crítico Álvaro Lins, colega de Oiticica no Colégio Pedro II, a exemplo do acadêmico Levi Carneiro, prefere silenciar sobre a ação política do companheiro, enquanto Peregrino Júnior, embora não omitindo o tema no já citado simpósio póstumo, deixa bem clara a sua posição ao afirmar que José Oiticica, "apesar de se dizer anarquista, era um dos homens mais corretos e dignos" que conhecera, além de chefe de família exemplar (6).

Ocorre que a intenção, velada ou ostensiva, de apagar das celebrações oficiais post mortem o legado anarquista do professor Oiticica, confronta com alguns depoimentos que nem sempre coincidem em relação ao peso da ideologia no conjunto da sua obra. Osório Borba, por exemplo, sem dizêlo com todas as letras, via a pregação anarquista de Oiticica mais como um gesto de generosidade intelectual do que como uma atitude amadurecida de consciência política, idiossincrasia que ele atribuía mais "à sua autenticidade, à sua total ausência de utilitarismo e arrivismo" do que a qualquer 
outra coisa. "Personalidade antitética - nos diz ele - o anarquista era, em filologia, um servidor devoto da disciplina gramatical", estranhando que, em poesia, Oiticica permanecesse "fiel aos rígidos cânones do parnasianismo" e que, na prisão, "como anarquista, participante ou envolvido na repressão de um movimento subversivo", se entregasse "à composição de um livro sobre o pronome $s e$ ". Ressalta, no entanto, que Oiticica permaneceria fiel até à morte à sua doutrina política, até "muito depois de o anarquismo ter desaparecido de todo o mundo como um movimento político viável, como um partido ( $s i c)$ capaz de atuar" (7).

Na verdade, se declarações como estas nem sempre fazem inteira justiça à obra do nosso Autor, é preciso acrescentar que o grande efeito produzido por elas foi inegavelmente o de terem posto em campos opostos o intelectual e o militante político. O primeiro, mais valorizado pela tradição acadêmica e por isso mesmo reconhecido por algumas vozes mais afinadas com as representações convencionais do saber, e o segundo francamente ignorado, quando não mitificado pela retórica dos depoimentos. Isto de certo modo justifica e esclarece as múltiplas visões conflitantes acerca do significado de José Oiticica, a ponto de não haver concordância nem mesmo em relação à contribuição do professor ou à filosofia de seu magistério. Cândido Jucá Filho dissocia o mestre do ideólogo, indo mesmo ao ponto de afirmar que foi na sala de aula que ele realizou o melhor de sua obra - o saneamento moral da juventude, que Jucá Filho chama de "obra socrática", de acatamento aos legítimos valores humanos, ao misticismo e à fraternidade cristã (8), definição em tudo oposta ao retrato traçado por Roberto das Neves - o de um mestre ateu que afrontava a Igreja Católica e a própria congregação do Colégio Pedro II, cujos membros, na ocasião de seu concurso de cátedra, chegaram - no dizer do crítico - "a argumentar com o perigo que para o ensino representaria a aprovação de Oiticica" (9). Talvez venha daí a forte impressão que este provocou num de seus discípulos mais brilhantes - o escritor Pedro Nava, então aluno do Colégio Pedro II -, que numa passagem de um dos volumes de suas memórias nos fala das aulascomício do mestre irreverente, obcecado o tempo todo por avivar a consciência da desigualdade entre os meninos (10).

Terá sido realmente esta a marca de sua contribuição mais fecunda?

Manuel Bandeira, ao relembrar num belo texto nem tanto o mestre, mas o Oiticica intelectual e agitador político, apesar de "bater continência" à bravura do batalhador que ele foi, considera com terna ironia que "a sua generosa ação anarquista não produziu a mais leve repercussão na massa do seu bairro sequer" (11). A avaliação, mesmo que inapelável (Oiticica já estava morto), não tem como se livrar de um certo desapontamento que ficou 
do episódio, já àquela altura distante, em que Oiticica aparece ridicularizando a fundo e sem contemplação os versos de Bandeira, a quem jamais perdoara a adesão aos modernistas de São Paulo, que, a exemplo de um outro anarquista - o escritor Lima Barreto -, ele considerava uns pequenoburgueses e gente sem a menor conseqüência (12). Seja como for, o que ressalta da crônica de Manuel Bandeira é que ela ilumina com grandeza a dignidade dos pequenos gestos e dos grandes equívocos que Oiticica, segundo ele, cometeu na vida. E aqui, mais do que a expressão do testemunho, é a arte do poeta que acrescenta à fisionomia intelectual do nosso Autor o aspecto que lhe faltava: o de que o batalhador Oiticica era "uma força lógica delirante" que se esgotava e renascia em cada batalha, fazendo dele um injusto por necessidade e um temerário por princípio e coerência, sem nunca ter deixado de ser probo.

Mais recentemente, e longe da perspectiva biográfica em que assenta grande parte de sua fortuna crítica, a pesquisa histórica vem demonstrando até onde chegavam as incursões libertárias do professor Oiticica. Nestas, o mesmo intelectual arrebatado que, no dizer de Manuel Bandeira, tentou demolir glórias definitivas como as de Alexandre Herculano e Gonçalves Dias, e que em São Paulo chegou a investir ruidosamente contra a competência dos integrantes do Congresso da Língua Nacional Cantada ali reunido por Mário de Andrade em 1939, aparece com uma face muito diferente do mestre que costumava despertar tanta admiração e temor reverencial em seus alunos (13). Através delas vamos aos poucos conhecendo o homem que desde 1913 falava aos trabalhadores no modesto recinto da Federação Operária do Rio de Janeiro e já no ano seguinte, com a fundação do Centro de Estudos Sociais naquele estado, dava início a uma longa marcha de batalhas cujo percurso permanece ainda hoje em grande parte disperso nas páginas de velhos jornais anarquistas e nos arquivos empoeirados dos documentos inéditos. O Oiticica de então, cujas palestras ao lado do escritor e teatrólogo Fábio Luz alvoroçavam as noites de sexta-feira naquela sede de trabalhadores, era já o homem que tinha muito clara na cabeça a necessidade, fundamental para as circunstâncias da época, de ajustar a ação intelectual ao avanço da questão social no Brasil.

Nessa tarefa, exprimiu-se em poesia, no teatro, no conto, na sátira, no drama, na comédia; escreveu cursos, preparou roteiros e programas para o rádio; adaptou o palco clássico dos gregos ao teatro volante de orientação anarquista (cenas-relâmpago, performances de rua no agit-prop das fábricas e de ação de greve), além de ter redigido ensaios teóricos e estudos críticos em quase todas essas áreas. Tudo isso agora vai sendo integrado aos novos 
fatos que, à luz da historiografia mais recente, vêm acrescentar à imagem retocada do "Oiticica sábio e erudito" uma dimensão até há pouco incompatível com a sua reputação de intelectual cooptado pelas elites ilustradas interessadas em mudar a fisionomia menos assimilável do anarquista destemido que ele foi e que não tem mais por que ficar apartada dos méritos, não menos louváveis por certo, do foneticista e do lingüista amplamente reconhecido por seus Estudos de fonologia (1916), o Manual do estilo (1926), o Método no estudo das línguas sul-americanas (1933), para não falar do Sistema fonético brasileiro (1941) e dos Roteiros em fonética fisiológica, e técnica do verso e dicção (1955).

O fato é que, depois que a investigação documental, apoiada em registros da época e louvada no testemunho pessoal de dezenas de participantes, reconstruiu a liderança e o papel decisivo de José Oiticica no levante anarquista de novembro de 1918, o que emerge do passado é a índole incendiária que torna quase inverossímil a figura do pacato professor que vai todas as manhãs ensinar empostação e prosódia aos meninos do Pedro II, com a batuta entre os dedos para acompanhar com precisão ora a leveza de um trecho de canto clássico, ora a escanção de algum verso esparso da tragédia grega ou da comédia latina.

Sabemos hoje que foi ele, e não outro, quem comandou o assalto frustrado ao palácio do governo no levante anarquista de novembro de 1918. Lendo os episódios daquela sublevação, nos inteiramos de que foi ele quem redigiu os boletins sediciosos distribuídos aos soldados da Vila Militar e planejou depois o ataque, reunindo os conspiradores em sua própria casa. E é nesta mesma casa que o vemos, em cena descrita por John W. Foster Dulles, na reunião decisiva da noite de 17 de novembro, advertindo o tenente Jorge Elias Ajus a que não debandasse à última hora porque o levante já estava nas ruas. O tempo corria contra os insurretos. Agripino Nazaré, também presente, lembrava que os tecelões já estavam mobilizados para a greve e naquela altura não poderiam ser dissuadidos a voltar atrás. Oiticica, nas palavras de Dulles, insistia com veemência em "que seria fácil tomar o depósito de armas e munições do Campo de São Cristóvão" e detalhava a estratégia com a qual os metalúrgicos cortariam as linhas telefồnicas e dinamitariam as torres de iluminação da Light, deixando a cidade às escuras. "Quarenta tambores de petróleo e gasolina - assegurava - seriam usados para incendiar o edifício da prefeitura, o quartel-general do Exército e o quartel central da polícia” (14).

O episódio, que parece nos remeter à atmosfera das aventuras de capa e espada, tem ao menos a virtude de registrar o desprendimento de uns poucos homens, hoje tão improváveis quanto a distância que os volatiliza 
no imaginário intangível das lendas. No entanto, por mais que nos vejamos tentados a prosseguir na paráfrase de suas façanhas, em busca talvez de uma grandeza com que jamais sonharam, o melhor é ficar por aqui e deixar para os historiadores a tarefa de avaliar o desfecho de suas investidas e as conseqüências que se seguiram à derrota dos conspiradores, traídos aliás pelo próprio tenente Ajus momentos antes da revolta, que culminaria com a prisão e a deportação de Oiticica, Astrojildo Pereira e Manuel Campos, com a dissolução da União Geral dos Trabalhadores pelo presidente em exercício Delfim Moreira e o fechamento de três sindicatos pelo chefe de polícia Aurelino Leal.
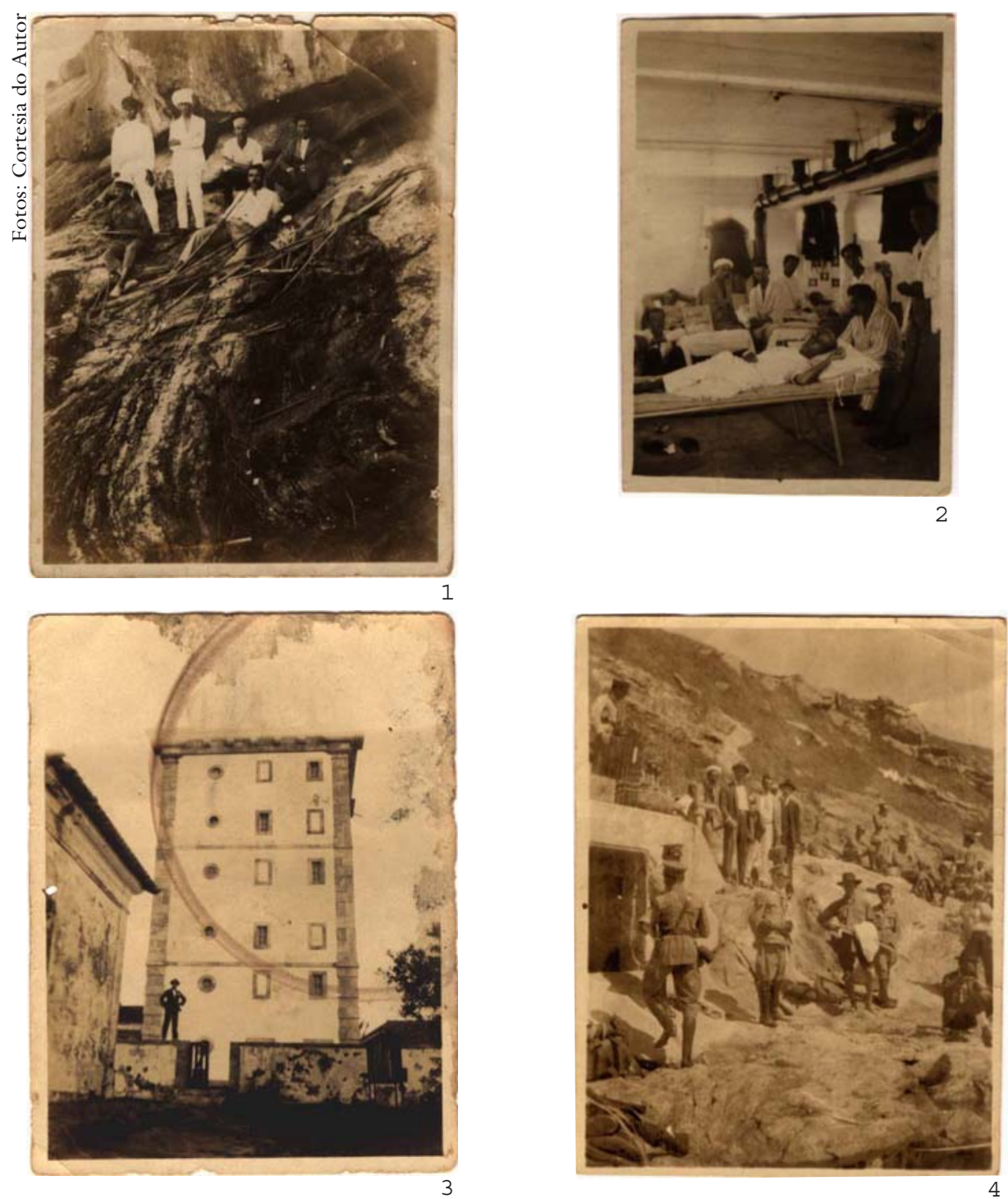

CENAS DA PRISÃO NA ILHA RASA : 1 Oiticica aparece deitado à frente ; 2 aparece de sarrete branco, à esquerda ; 3 à frente do edifício da prisão e 4 aparece de sarrete branco, à esquerda. 
Por mais que tais acontecimentos nos digam respeito, não é esse o objetivo do presente ensaio. O que aqui nos ocupa é sobretudo o interesse pelo teatro, que então se manifesta e vai tomando corpo à proporção que se expande a ação libertária do imprevisível professor, logo depois da sua volta de Alagoas, em 1919, quando funda com Astrojildo Pereira, no Rio de Janeiro, o jornal Spartacus. Espalhada em jornais e revistas, ou mesmo dispersa em manuscritos ainda por editar, grande parte desses escritos foi redigida na cadeia, primeiro na ilha Rasa, por ocasião dos acontecimentos de 1924, depois no confinamento da ilha das Flores e, a partir do ano seguinte, quando escreve no cárcere $A$ doutrina anarquista ao alcance de todos e esboça a trama da peça Azalan!, nas mais diversas circunstâncias em que se viu envolvido pelos compromissos da luta social.

Da volta do segundo desterro, quando lança o jornal clandestino 5 de Julho, à fundação do primeiro Ação Direta, em 1929 (o segundo só viria em 1946 e seria editado até o ano de 1958), são inúmeros os textos ficcionais e de crítica teatral que se juntam aos trabalhos já publicados que incluíam, naquela altura, além dos versos convencionais dos Sonetos (1911) e da Ode ao sol (1915), toda uma série de poemas satíricos e de versos políticos publicados na imprensa operária e dispersa em jornais como $A$ Lanterna, na revista $A$ Vida, no Spartacus, no Ação Direta, no Livre Pensador, n'A Plebe etc.

Nesse conjunto, o bloco teatral ocupa uma posição destacada. $\mathrm{Na}$ verdade, as elucubrações dramáticas do professor Oiticica vêm de mais longe e já eram relevantes na época em que ele lecionava no Colégio Pedro II, como se pode verificar do bloco de fichas em que planejava as suas aulas - um maço de velhos manuscritos meticulosamente anotados a lápis com remissão a peças, páginas, cenas, versos, atos e aparato bibliográfico, entre os quais uma saborosa marginália aos textos de Aristófanes, que o mestre vai aos poucos travestindo de anarquista segundo um cuidadoso roteiro ilustrado com exemplos e falas não raro entrecortadas de comentários espirituosos e cheios de ironia. Fico pensando na reação dos alunos ao verem aquele homem de grossas sobrancelhas gesticulando e carregando na imitação impostada das vozes velhacas que ia tirando da interminável galeria de malandros com que Aristófanes - o primeiro anarquista do teatro ocidental, segundo ele - recheara a comédia antiga.

O roteiro era implacável: mais talvez que a aura solene da biografia do poeta do século de Péricles, ou mesmo que a demonstração analítica da estrutura dramática da comédia enquanto gênero (os cuidados com o prólogo, o párodo, o agon e a parábase), o que as aulas de Oiticica perseguiam era a expansão ideológica de um conceito que empolgasse os alunos em torno da 
libertação da consciência dos homens. Sob este aspecto, suas preleções eram verdadeiros laboratórios para a discussão e a revolta. Em vários momentos da leitura de Pluto, em que o pobre e honesto Crêmulo, aconselhado por um oráculo, persegue e se apodera de um velho cego que vem a ser ninguém menos que Pluto, o deus da abundância e da riqueza, os tópicos escolhidos para a preleção não escondem o desejo de convencer os alunos de que numa sociedade de competição animada pelo dinheiro ninguém ganha nada em ser honesto.

$\mathrm{Na}$ demonstração de sua tese, Oiticica transcreve algumas falas de Crêmulo e Cárion: o primeiro lamentando-se de que enquanto se manteve piedoso e honesto, dirigiu mal os seus negócios e acabou como um miserável, ele - Crêmulo - que se cansou de ver "os maus gozando dos bens adquiridos pela injustiça, enquanto as pessoas de bem viviam em geral na miséria e morriam de fome". Cárion, em resposta que o professor grifou de vermelho, apenas confirma a tese, ao dizer que até um cego era capaz de ver que a honestidade e o dinheiro eram coisas incompatíveis.

Até que ponto - era a pergunta que o professor reservava aos seus alunos - não seria o povo, que ajudava a escolher os seus governantes, o responsável por esse descalabro?

A lógica das fichas elabora o argumento. E quem socorre o mestre é o Coro de Os cavaleiros, uma comédia escolhida a dedo por conter um violento ataque de Aristófanes ao demagogo Cleon, ali representado como escravo favorito do estúpido e irascível Demo, até ser afastado de suas funções por Agorácito, um tripeiro com vocação ainda maior que a dele para a canalhice e a pouca vergonha. Oiticica previa os alunos ao lado do Coro, particularmente na cena em que este sacode os brios do Povo, do qual desdenha e chama de velho: "Todo mundo te tem como a um senhor, mas tu és maleável e te deixas governar de bom grado por aduladores e subornantes...”. O próprio tripeiro põe fogo nessa briga quando joga na cara de Cleon a acusação de que este, demagogo, faz de tudo para que o povo não se aperceba de suas ladroagens, e mais: que, apertado pela carestia e a necessidade de garantir um salário, fica obrigado a esperar exclusivamente dele, Cleon, as decisões sobre a sua própria sobrevivência.

O melhor, no entanto, ficaria para a última parte da aula, na qual a intenção é fazer ver aos alunos que ao governo não interessa o povo instruído e honesto: "só lhe serve o ignorante e o maroto". A demonstração da idéia sai de um saboroso diálogo em que Demóstenes afaga ironicamente as veleidades do tripeiro, que desejava saber dele como poderia se transformar num grande homem para assim chegar ao poder. "Serás grande porque és 
um patife sem vergonha, um filho dos açougues" - responde Demóstenes: "tudo conspira para a tua grandeza". E como o tripeiro insistisse na questão, dizendo que não podia compreender que um homem simples como ele pudesse chegar um dia a governar o povo, Demóstenes volta à carga com uma contundência ainda maior: "Nada mais simples" - responde. "Continua no teu ofício e mistura e amassa bem todos os negócios do Estado como quando fazes lingüiça. Para cativares o povo, cozinha-lhe sempre algum prato que lhe agrade. Tens, aliás, tudo o que vale a um demagogo: voz terrível, natureza perversa e linguajar dos açougues".

Demolida a falsa respeitabilidade dos governantes, o roteiro dramático-libertário das aulas de Oiticica reserva ainda aos alunos uma boa coleção de tópicos básicos da filosofia anarquista. Nas Vespas, por exemplo, o professor serve-se de Aristófanes para repudiar a volubilidade da justiça e a arbitrariedade dos impostos, que entram na aula como uma forma de demonstrar que o mal de todos os governos é que eles têm a faca e o queijo na mão para “assaltar a economia do povo e proteger os poderosos". No em-

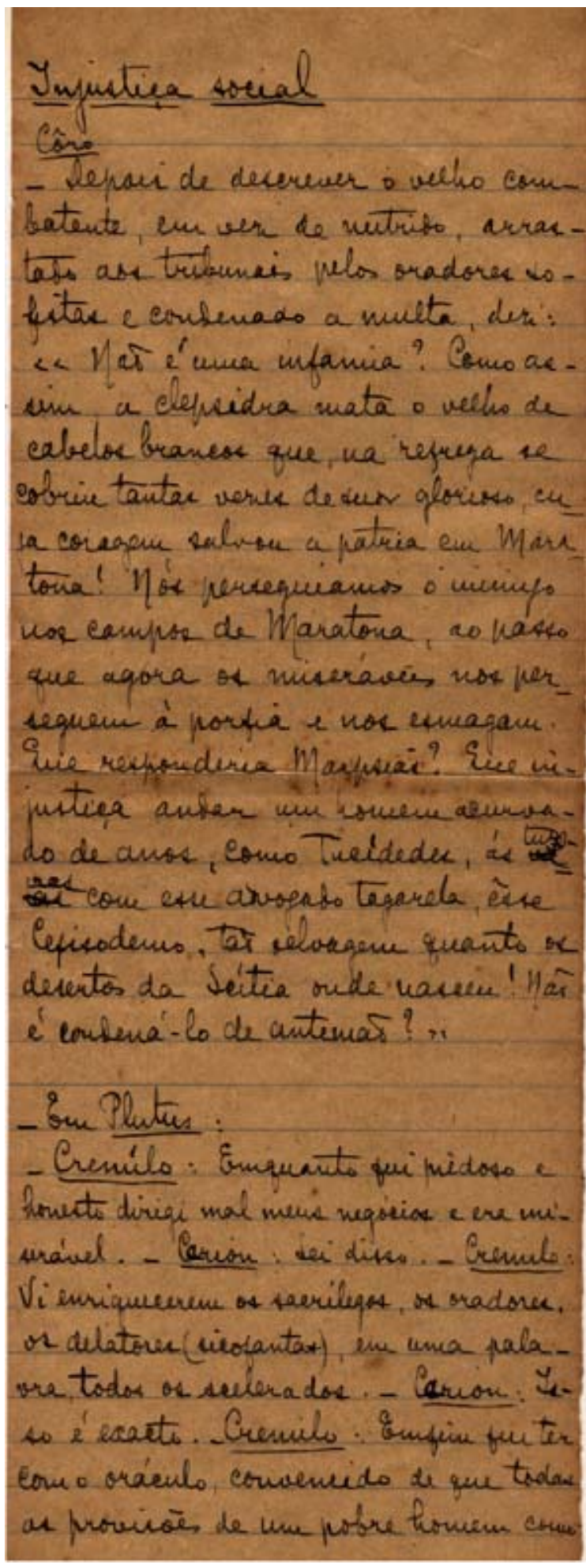

Fac-simile de uma das fichas de aula sobre o teatro de Aristófanes 
balo da sátira que faz Aristófanes do excesso de litigância dos atenienses nas figuras do velho Filocleon e seu filho Bdelicleon, que consegue para o pai o privilégio de manter um tribunal em sua própria casa, Oiticica leva os alunos para o interior das mazelas da justiça. A partir de uma fala de Bdelicleon, na qual se lastima de que o pai, um jurado da corte, faça parte de um tribunal comandado pelos poderosos e feche os olhos para a bajulação e o conchavo entre réus e juízes, seu roteiro se detém no exato momento da exortação que o filho, indignado, faz ao pai: "salta sobre eles furiosamente [porque ] se eles quisessem assegurar o bem-estar do povo nada lhes seria mais fácil”.

O antimilitarismo é outro tema de que o mestre se vale para, através de Aristófanes, mostrar aos alunos a inutilidade da burocracia das armas. Na comédia Os Acarnianos ninguém melhor do que Dicépolis - o fazendeiro, herói que mantém um tratado de paz em separado com os lacedemônios para revolver os bastidores da guerra, onde o confisco, o contrabando, o banimento de gente honesta, o oportunismo dos mercenários, o heroísmo individualista e o patriotismo despontam como coisa corriqueira na diluição das diferenças entre o dever e o crime. No transcorrer da cena a ser comentada em aula, Dicépolis pergunta a Lâmaco, por exemplo, quem seria mais virtuoso: o ancião de cabelos brancos que vai para a linha de fogo em defesa da pátria e quando volta (se é que volta), orgulhoso do dever cumprido, em geral morre pobre e esquecido por aqueles que ajudou a defender, ou o jovem que se furta ao serviço militar e, mesmo sem pegar em armas, muitas vezes é premiado com uma boa embaixada ou um alto cargo que lhe rende muito dinheiro...

Noutra passagem, agora de As nuvens, Oiticica se aproveita para destacar a iniqüidade absurda dos agiotas, valendo-se da discussão em que o Primeiro Credor, tentando explicar a Estrepsíades a importância dos juros (e convencê-lo a pagá-los), lhe diz que através deles o dinheiro vai aumentando pouco a pouco a cada mês. O que o professor quer tirar do episódio, no entanto, é a resposta de Estrepsíades, que ele igualmente circula em vermelho: "Se o mar para onde correm todos os rios não é maior hoje que outrora, como ousas dizer, patife, que teu dinheiro aumenta por si mesmo? Some-te daqui! ”.

Na mesma ficha de aula, estão o desabafo de Crêmulo, no Pluto: “o dinheiro é a causa única de todos os males e de todos os bens", e também, em As aves, a resposta da Pomba a Evelpide, interessada em saber como era a vida entre os pássaros. "Não é desagradável - diz a Pomba - em primeiro lugar porque vivemos sem a presença do dinheiro". "Eis aí, de menos, um dos maiores males", acrescenta Evelpide. 
A estes se juntam outros extratos que poderíamos continuar enumerando indefinidamente. A ridicularização dos adivinhos como impostores e parasitas e a expulsão dos legisladores em As aves; o argumento, em As nuvens, a favor do adultério e dos conflitos entre a religião e a moral social; a revelação, em Plutus, de como os sacerdotes furtam os devotos nos sacrifícios; a fala de Mercúrio, nessa mesma comédia, desqualificando a pátria como uma abstração da identidade nacional ("Pátria é todo lugar onde nos achamos bem"); a queixa de Xantias, em As vespas, sobre a indignidade da condição de escravo; o processo, em $A$ paz, para impedir os escravos de comerem a farinha que eles próprios fabricam; a boa nova do projeto comunista de Praxágora n'As oradoras e por fim a revolta feminina na Assembléia das mulheres, que ocupam a cidadela de Atenas (a Acrópole) e assumem o poder e a direção do Tesouro, propondo uma nova ordem marcada pela socialização da riqueza, da propriedade e do sexo.

Se nesses roteiros de aula os personagens alegóricos de Aristófanes se transformam em porta-vozes programáticos da ação libertária de Oiticica - a essa altura enfiado até à raiz dos cabelos na frente de ação política -, noutros apontamentos as anotações servem de base ao estudo teórico do teatro, visando não apenas à sala de aula ou aos manuais acadêmicos, mas também à produção de suas próprias peças.

Para Oiticica, por exemplo, todo enredo é um ato ou seqüência de atos de que a personagem é a executora, o "elemento figurativo do enredo" (15), ocupando aí uma posição inferior à do tipo. Para quem imagina o que foram as representações teatrais dos anarquistas, nas quais o episódio encenado era parte de um espetáculo mais amplo que englobava peças musicais, discursos, conferências e concursos de rifas e prendas em geral encerrados por um baile - a ênfase de Oiticica para a expressão figurada da personagem deriva da própria concepção do espetáculo como uma atividade de base popular e ideológica que funcionava como um elo de ligação dos trabalhadores, quase sempre realizada na sede de sua liga profissional para comemorar uma data representativa ou mesmo para arrecadar fundos em favor de companheiros presos.

Tal noção ganha funcionalidade na hipótese de Oiticica porque em tais espetáculos ficção e realidade entram como categorias complementares de um episódio cujo desfecho, mais que estético, é exemplar e denotativo de uma experiência vital para a platéia. Nele, a história jamais deixa de ser vista como "uma seqüência de episódios tramados por personagens seres vivos, componentes de uma vivência plural, de um enredo realmente vivido" e que, embora não devam ser confundidos com o universo imaginário da ficção, ganham força ainda maior quando se transformam na realidade figurada do palco. 
Nessa passagem do histórico para o estético, o resultado mesmo sendo diferente da experiência vivida, só terá conseqüências se definir uma atitude em relação ao embate entre o imaginado e o efetivamente existente, coisa que segundo Oiticica só poderá se verificar através do que ele chama de caráter da personagem e da construção literária ou dramática, ou seja: a força ideológico-moral do herói ou da verdade que ele representa. "Nessa caracterização - nos diz ele - o autor tem de atender a alguns determinativos: condição social, estado mental, época ambiente, seu mister no enredo, pressões deformantes, fins visados etc.”.

Isso explica que em torno do caráter da personagem todos os recursos se admitem, sejam eles de que natureza forem, na chave estética como na chave ideológica. Oiticica lembra a propósito o exemplo de Racine, que, acusado por seus contemporâneos de haver deformado a história, justificou-se no prefácio a Andromaque "contando o que fizeram Eurípides e Ronsard em matéria de adulterações históricas”. Assim, se é verdade que o teatro pode deformar os episódios que efetivamente aconteceram na vida real, o sentido maior ou menor dessa deformação só se sustentará se conseguir revelar uma nova verdade, a verdade dos personagens articulada com a verdade dos espectadores em função da realidade que os identifica.

Neste particular, são conhecidos os efeitos extraordinários que o espetáculo anarquista costumava exercer sobre suas platéias, particularmente na Europa. Reproduzida numa crônica do jornal livre-pensador (mas não anarquista) espanhol $\mathrm{La} L u z$, sobre a célebre noitada em que os anarquistas de Barcelona, em março de 1886, encenaram a farsa El arcediano de San Gil - cujo argumento expunha no palco as torpezas de um clérigo libidinoso lemos no Musa Libertária, de Lily Litvak, que o imenso auditório, revoltado diante daquela imoralidade, chegou quase a fazer justiça com as próprias mãos. "Matem-no! - gritava indignado um espectador recalcitrante que não podia suportar a exibição de tanta vileza. D. Pedro, o Cruel - conclui o relato - satisfez àquela justa petição, condenando a ser enterrado vivo o ministro de um senhor que ninguém jamais conheceu” (16).

Na revelação dessa outra ordem, que entre nós não chegou necessariamente a instâncias tão trágicas, resumindo-se a ser apenas a ordem arbitrária da criação intelectual, de cujas leis só a retórica do texto e a da subjetividade podem dar conta, o caráter da personagem principal - como o imagina Oiticica - não vem nunca desacompanhado das vozes ressonantes que a confirmam ou restringem, desintegram ou repudiam através das falas secundárias que interferem nas diferentes instâncias da ação, ao se ajustarem, por exemplo, às exigências contextuais do argumento (personagens 
ambientais); ao entrarem em cena com a finalidade exclusiva de revelar um incidente modificador do desfecho (personagens acidentais); ao auxiliarem a articulação do discurso do herói ou da personagem principal, como o confidente ou a alcoviteira, por exemplo (personagens articulatórias); ao se reduzirem a meros apêndices ou a aparições momentâneas destinadas a motivar a efabulação (personagens ornamentais e personagens transitórias) etc.

Todas elas de uma forma ou de outra interferem na evolução dramática do protagonista, provocando a expansão de um efeito artístico (caracterização) e constituindo-se em elementos fundamentais da inventividade do teatro. Sob este aspecto, apesar de identificado com a produção ideológica da catarse libertária, o teatro de Oiticica é muito mais o projeto de uma concepção de autor do que propriamente uma opção intelectual vinculada às teorias anarquistas do teatro total nos termos em que o conceberam militantes como Errico Malatesta e Jean Grave, por exemplo, para quem o espetáculo deveria emancipar-se totalmente da estrutura econômica do teatro burguês, sair das mãos das empresas comerciais e assumir-se como uma intervenção que eles consideravam o teatro livre, ou seja: um espetáculo inteiramente concebido e realizado pelo povo, da autoria à concepção, da coreografia aos cenários, passando por os figurinos, a música, os ensaios, a direção etc.

$\mathrm{Na}$ concepção de Oiticica, ao contrário, as personagens, o tipo e a trama têm estatuto intelectual independente. Ele argumenta que as personagens desafiam o poder de invenção do dramaturgo para contrapor-se ao arcabouço ideológico-moral do tipo, em geral mais próximo da capacidade de observação crítica do autor. Com isto, não é raro que este último se veja por vezes obrigado a criar personagens postiças, como fez Corneille em relação à rainha Viriata no Sertorius, para explorar esta ou aquela carência do tipo central em torno de quem muitas vezes se desenvolve o argumento. Não que o tipo se confunda com a personagem principal, embora nada impeça que esta última possa ser típica. A Oiticica o que interessa é sobretudo marcar a expansão da ação através das polaridades do conflito, como aliás ocorre no espetáculo popular anarquista. Para ele, ao contrário do que se dava com as peripécias do teatro livre, não há personagem sem episódio dramático, sendo que, neste, o papel figurativo da personagem é o de amarrar e ampliar a intriga até que o desfecho sobrevenha. Daí que em seu teatro a personagem seja menos acabada que o tipo, pois a trama é, para ela, uma etapa para chegar - ou não - à própria realização ou à concretização de seus objetivos, ao contrário do tipo, que evolui apenas numa única direção, sejam quais forem as conseqüências. 
É neste passo que se revela a importância do tipo na teoria das personagens de Oiticica, pois ao revelar-se um caráter largamente modelado, imutável e circunscrito à encarnação de uma idéia permanente (a avareza de Harpagão em Molière, do velho Grandet em Balzac, de Shylock em Shakespeare), ele em geral desencadeia a reação imediata de seus oponentes, o que faz crispar a ação e ampliar as modelações do caráter na raiz ideológica de seu real significado. Ou seja: contra o tipo em geral se articula todo o movimento da expansão coletiva de uma força oposta que o contesta e combate, acelerando a lógica inevitável de sua superação, como nos melhores desfechos da encenação libertária popular. Do ponto de vista desta última, essa é uma questão importante, pois nos pode revelar - como aliás pretende Oiticica que nem todo tipo é permanente. "Um tipo comezinho numa época, pode desaparecer para sempre", nos diz ele, argumentando com o exemplo do próprio avarento, tido até hoje como um tipo eterno, mas que, "com o desaparecimento inevitável do capitalismo, regime social calcado no dinheiro", poderá reduzir-se à mera excrescência arcaica destituída de qualquer interesse e permanecer circunscrito apenas ao âmbito dos textos, em face dos quais jamais perderá vitalidade.

Das peças ideológicas de José Oiticica, Azalan! é a única que trata propriamente da ação revolucionária, diferentemente de Pedra que rola e de Não é crime, que apesar de textos programáticos, exercitam no palco-como veremos - uma espécie de drama de costumes temperado pela atmosfera conflituosa dos temas libertários.

Em Azalan! o herói é Sérgio, um revolucionário anarquista que está preso na ilha de Fernando de Noronha por haver cometido o crime de fabricar moeda falsa em favor da libertação dos trabalhadores. Como em geral ocorria com os heróis do teatro popular libertário então encenado no Brasil, ele encarna no palco uma reivindicação atual, defende uma concepção de mundo e luta ao longo da trama pela redenção dos destituídos, com o mesmo espírito que marcara os protagonistas de alguns espetáculos decisivos para o avanço do teatro anarquista, como o jovem libertário Júlio de O semeador, de Avelino Fóscolo, que recém-chegado da Europa, onde estivera em combate e conhecera os princípios do anarquismo, resolve enfrentar o cunhado Lima e revolucionar as relações de trabalho na fazenda do pai, coronel ganancioso, dividindo as terras com os empregados, promovendo a mecanização da lavoura e diminuindo a jornada de trabalho em benefício de todos. Ou ainda como Paulo, o bravo militante operário que em Bandeira proletária, de Marino Spagnolo, leva os companheiros a resistirem sem trégua e a tomarem consciência do que significava trabalhar para o interesse dos patrões, ali simbolizados pela astúcia do lúbrico Fernandes. 
A importância da peça, contudo, não vem apenas desse fato, o único aliás no teatro de Oiticica em que o protagonista fala de seus planos de combate. Mas vem também do fato de que entremeia ao tema de fundo uma crítica difusa que atravessa o contexto social do argumento e vai registrando, aqui e ali, num andamento até certo ponto incompatível com o dos espetáculos populares, os sintomas do atraso, como a crendice, o linguajar primitivo, a ingenuidade e o ronceirismo das personagens da ação.

Em Azalan! esse traço fica por conta de Dionísio, um presidiário já velho, dos tempos do Império, pobre diabo que espera a volta do Imperador e vive obcecado pela palavra mágica azalan! revelada por uma certa princesa Magalona, que vive encantada no fundo do mar e aparece, na cena de abertura, prometendo-lhe o tesouro enterrado na ilha, em troca de uma obrigação que a livraria para sempre do tal encantamento: repetir três vezes a palavra mágica, depois de jogar uma donzela viva no oceano. "Ela me disse mode atirá uma donzela viva no má e gritá Azalan trei vez... Eu vô sê o rei dos home! Eu bem sabia que ela ia aparecê... uma coisa me dizia... Eu vô tê dinhero... muito dinhero...".

Para o leitor, é fácil imaginar o contraste que logo se estabelece entre uma elocução como esta e o tom elevado das falas e dos interesses do herói anarquista no contexto ideológico da peça. Ex-escravo, Dionísio anda cheio de "miçangas, colares, pulseiras de toda espécie, medalhas de lata e papelão pintado, cinto de cipó com folhas", a barba grisalha, os cabelos desgrenhados e longos, compondo em tudo um tipo que se sobrepõe à caracterização sumária e quase inexistente dos personagens-programa do teatro anarquista. Além disso, falando como um primitivo, dilui-se no uso irônico e quase folclórico da linguagem da gente simples que faz contraste com o rigor da fala das outras personagens - traço comum nas peças de Oiticica, sempre rigoroso na observação do vernáculo. O que ocorre é que, por si só, o recurso a esse desvio exótico mantém na trama a expectativa de um desfecho paralelo que rivaliza com o peso ideológico da missão revolucionária de Sérgio e altera a fisionomia dramática do espetáculo em relação às encenações ortodoxas dos anarquistas. Afinal - pondera o leitor -, será Clotilde (filha donzela do diretor do presídio, que se apaixona por Sérgio e rompe depois com a família) a vítima inocente a ser jogada no oceano?

Não que Oiticica não aproveite os motivos dessa dissonância para encorpar as conviç̧ões libertárias do protagonista. Embora os trate com a distância da ironia e da complacência (no primeiro diálogo, por exemplo, Sérgio pergunta a Dionísio quando chegaria o Imperador ...), eles servem de apoio à fixação do caráter do herói ao longo de uma trama que, se a 
exemplo do teatro militante da época, nos deixa a impressão de obra pouco realizada, nem por isso se resume apenas a um espetáculo que avança à base da declamação e do discurso, a partir de arquétipos ideológicos mais que de personagens.

Em diversos momentos da peça a verdade dos prisioneiros pobres revela o tratamento diferente na definição dos crimes que cometeram. Generino - outro pobre diabo, condenado por furto de cavalo - e Dionísio, preso por ter matado o dono da senzala que tentara seduzir-lhe a filha, aparecem como "vítimas" ao lado de Sérgio, que nada tem de falsário ou de criminoso comum. "Todos aqui são vítimas - nos diz ele -, pobres vítimas... Mataram ou furtaram porque a isso os impeliu a fome, o álcool, a doença, as perseguições dos superiores, a politicagem de seus amos, a superstição, a ignorância, todas as misérias que os dirigentes do mundo inteiro vão mantendo porque lhes convêm".

Tudo isso concorre para que o argumento de Azalan!, escapando da regra da brevidade, tão característica da encenação convencional do teatro popular anarquista, não se resuma apenas à transformação de Sérgio de bandido em herói redentor. Uma de suas variantes mais expressivas é o episódio do amor de Clotilde por Sérgio, que pouco tem a ver com a voluntariedade do casal libertário consagrado na clássica imagem do par proletário que enfrenta todos os obstáculos em busca da própria realização, superando ora os patrões poderosos - como no caso de Adelina e Leonel na trama de Gaspar, o serralheiro, de Baptista Machado -, ora os preconceitos da família burguesa, como ocorre com o infatigável Roberto nas cenas de $O$ $i d e a l$, de Pietro Gori, em sua luta por transformar o inconformismo pequeno-burguês de Maria em instrumento de sua própria libertação, seja em relação ao pai, o burguês Adorni, seja em relação a Ugo, amigo de Adorni e pretendente inoportuno.

Em Azalan! nada disso acontece. O amor de Clotilde por Sérgio é mais uma paixão típica de drama romântico, sentimento não correspondido e muito longe das virtudes inquebrantáveis das heroínas da dramaturgia popular. Ingênua e simplória, a personagem Clotilde entra em cena unicamente com a função de revelar a identidade do herói, sem o menor compromisso de acompanhá-lo em sua trajetória rebelde. Nada há que justifique sua paixão a não ser a intuição, que ela transforma em certeza, de que Sérgio não podia ser um criminoso comum e portanto cumpria pena sob condição de inocência.

O próprio Sérgio nunca alimentou esse amor: declarando-se noivo de Clara, trata a moça com a distância que convém à retórica dos heróis que 
não se deixam dobrar pelas fraquezas de momento. Mais ainda: por julgá-la ingênua e despreparada, ele mente para ela, dizendo-se criminoso, que fabricara moedas falsas com o intuito de "ficar rico e ... ser feliz em tudo". Clotilde insiste, mas o herói não se convence de que ela pudesse compreender o que fosse efetivamente uma decisão revolucionária. De modo que entre eles o amor não se concretiza: por mais que isso a faça sofrer, o máximo que o herói se permite é chamá-la de "irmãzinha" - ele que, sem que Clotilde pudesse imaginar, era na verdade um revolucionário destemido, duas vezes processado como falsário, fugitivo da cadeia de Garanhuns e ativista caçado por todo o estado de Alagoas, onde denunciara pela imprensa as ladroeiras do comissário de polícia e acabara nas mãos de um destacamento de soldados armados até os dentes.

No entanto, e aqui estamos diante de outro desvio, mesmo sendo uma voz fundamental na revelação do caráter do protagonista, Clotilde não pode ser incluída entre as personagens-espelho tão características do teatro popular anarquista, por simbolizarem no palco a manipulação ideológica indispensável ao processo de formação libertária da platéia, como na célebre conversão de Libério, o moço indiferente que adere ao anarquismo ao compadecer-se da espoliação sofrida pelos pais em Militarismo e miséria, de autor desconhecido (17). Ao contrário, por exemplo, de Rosa, a viúva pobre de O pecado de Simonia, de Neno Vasco, que vende um crucifixo para comprar bilhetes de loteria sob as vistas cúmplices do padre João, que a cobiçava, mas que no final recupera o senso das coisas e se livra das chantagens da Igreja graças à ação doutrinária de Ciro Leal, o namorado da filha, de quem sempre desconfiara. Clotilde não se converte à razão anarquista nem mesmo quando, no final da peça, garante a fuga de Sérgio ao matar com um tiro de revólver o guarda que tentara detê-lo. E esse seu gesto de ousadia nem de longe se compara ao efeito espelhado da revolta das vizinhas (a viúva Luiza e Joana, a mulher do sapateiro), na cômica seqüência de vassouradas que desmascaram o padre Joaquim e o remendão João das Rendas, um vestido de Senhor Bom Jesus, o outro de São José, quando tentam se passar por santos para obter as graças da viúva no final da farsa Vozes do céu, de Mota Assunção, cujo desfecho exemplar transforma as duas protagonistas em autênticos reflexos da catarse do público, que afinal ri aliviado diante do desmascaramento de tanta hipocrisia.

O próprio Sérgio, que simboliza na peça a metáfora anarquista do libertário como soldado da humanidade, acima do bem e do mal, não chega a dar estabilidade dramática aos valores que representa. Assediado pelo amor inocente de uma moça de província, acaba por exemplo se confessando demais e abrindo-lhe detalhes inconcebíveis para um militante de seu 
porte, que deveria ao menos se resguardar dos perigos de uma possível armadilha. Clotilde era enfim a filha do diretor do presídio e, moça simplória, bem poderia, mesmo que involuntariamente, passar ao pai as informações sigilosas que recebera. Afinal Sérgio lhe confessara que fabricava dinheiro falso "para a libertação dos brasileiros", que tinha aliados revolucionários agindo em São Paulo, no Rio de Janeiro e em Pernambuco. Mais: descreve-lhe detalhes de um plano de fuga, diz-lhe para onde vai, com quem vai se encontrar, o horário, o dia - coisas que, vistas em conjunto, não combinam com o perfil heróico de suas falas, em nada semelhantes à elocução dos heróis recitantes do teatro da militância, dos quais raramente se aproxima. Por exemplo: quando Clotilde, já no final da peça, lhe diz, cheia de cerimônias: "Sinto que sem o sr. eu não posso viver", ele "num grande transporte, agarrando-lhe a cabeça", responde, como se falasse para a humanidade: "Predestinada! Como sinto a alma profunda da minha raça bramindo nestes olhos!”.

Desviado, assim, para a instância melodramática, o argumento de Azalan! destoa da estrutura do teatro libertário militante, em que predominam a brevidade do episódio, a simplificação da trama (com destaque para o ato único), a clareza da mensagem e a repetição dos motivos dramáticos na articulação dos temas, das moralidades e dos esboços ideológicos próprios do teatro didático-propagandístico, em que as rubricas quase não têm função cênica ou caracterização de personagens, o monólogo entra como modalidade básica e as falas exigem do ator uma atitude recitante próxima da declamação, de que são exemplo clássico os apartes do Estrangeiro no Primeiro de maio, de Pietro Gori (18).

Em Azalan! a irregularidade da ação faz com que os aforismos anarquistas brotem de contextos os mais inesperados. Da boca do primitivo Dionísio saem por exemplo alguns dos mais pertinentes, como o da cena VII do primeiro ato, que toca na essência da contradição militarista, quando o ex-escravo diz não compreender por que o prenderam quando degolara o coronel que atentara contra sua filha: "Foi o guvêrnu memo que me mandô matá (na Guerra do Paraguai) e odepois ainda mi deu condecoração, três medaia. E depois, como eu matei um home ruim que queria desonrá minha fiia, eles me condenaru cumo criminoso".

É verdade que Sérgio, mesmo enfraquecido na teia do atraso e da pieguice, consegue revelar seu perfil revolucionário, não apenas por conseguir escapar da prisão para voltar à ação militante das ruas, mas em especial por compensar a frustração de não haver doutrinado nenhum personagem com uma série de juízos que amarram o frouxo andamento da peça a mo- 
tivos libertários que permanecem vivos. Entre eles, a tese de que todo dinheiro é falso (e não apenas aquele que ele fabrica), por ser "o instrumento que têm os ricos não produtores de riquezas para arrancar dos trabalhadores as riquezas produzidas por eles"; a metáfora libertária da terra como $\mathrm{um}$ vastissimo presídio, onde se torturam milhões de vítimas para fartar uma pequena porção de homens insaciáveis; antítese da descrença na ordem jurídica e da crença na sua superação ("descri das leis e comecei a cogitar nos meus pobres patrícios, naqueles jagunços de Canudos, do Condestado, dos famintos do Nordeste, nos fanáticos do padre Cícero"); e por fim a apóstrofe da ação libertária pela revolução como única alternativa para unir os despossuídos e "fundar uma nova república, a dos verdadeiros brasileiros, contra a república dos brasileiros ricos aliados aos estrangeiros ricos".

Clotilde, no entanto, não consegue superar a limitação ideológica que a paralisa no palco. Inconformada com a perda do homem a quem ama, chega a pensar em denunciar ao pai os preparativos de sua fuga, só não o fazendo porque Anselmo - um capanga do pai que a desejava - a surpreende beijando o herói pouco antes de este deixar o presídio. Era o momento em que Sérgio se despedia e ela, segurando-o pelos cabelos, tentava beijá-lo de novo. Ele se desvencilha ("vou, preciso ir para a grande obra... espero-a lá... adeus"), mas ao sair é cercado por Anselmo, que avança decidido a prendê-lo. Clotilde então puxa o revólver e mata o intruso.

O que se segue é na verdade um arrebatamento típico dos desfechos românticos mais descabelados. Desesperada com a partida do companheiro, Clotilde grita por Dionísio, pedindo-lhe que a jogue ao mar. "Venha, Dionísio, estou pronta. Dionísio! Dionísio! Eu quero morrer”. Uma voz misteriosa ecoa então pela cena: - Azalan! E a peça, libertária, termina estranhamente sob o signo da crendice e do folclore.

Sérgio, entretanto, é o único libertário ortodoxo do teatro de José Oiticica. Nas outras peças doutrinárias que escreveu, ele amplia ainda mais essa vocação desviante e põe em cena personagens tão incaracterísticas quanto as ciladas em que as enreda, cheias de inversões inesperadas e quase sempre indefinidas entre o dramático e o cômico, o exagero da inflexão doutrinária e a gratuidade das soluções cênicas.

No centro de Pedra que rola, por exemplo, numa espécie de figuração do inocente imprescindível à sobrevivência dos valores burgueses, está Jorge, "um fanático do papa e da realeza" que, por ter sido protegido e enca- 
minhado na vida pelo padrinho Bernardo, resolve demonstrar-lhe toda a sua gratidão, defendendo-o como um cão de guarda.

Bernardo é um negociante português cheio de dinheiro, porém mesquinho e ressabiado tanto quanto católico fervoroso e admirador da monarquia. Casado com Corina, uma mulher ladina e muito mais jovem do que ele, vive de casa para o trabalho, e pouco oferece à mulher, além de uma vida doméstica folgada e livre de preocupações.

Jorge, que sabe das frustrações de Corina, ama-a em segredo, mas é incapaz de se declarar, tolhido que está pelo dever de respeitar a mulher daquele que o tirou da pobreza e lhe deu casa, comida e trabalho. Vivendo essa verdadeira provação, decidiu compensá-la a cada dia com uma fidelidade cada vez maior à pessoa e às coisas do padrinho.

Diante desses caminhos entrelaçados, Oiticica consegue pôr no palco alguns dos motivos mais caros ao espírito corrosivo dos anarquistas. Afinal, Bernardo - além de homem endinheirado - encarna o velho português catolicão e monarquista, serviçal de Deus e da Coroa, mas enrabichado aos encantos da jovem esposa, a quem exibe como um objeto adquirido a peso de ouro, subjugando-a como proprietário e senhor.

Corina faz o jogo do velho e mantém as aparências de esposa fiel, em claro contraste com Jorge, que, mais do que cão de guarda, é o defensor da moral da família e o paladino da honra do padrinho (no dizer de uma das personagens, lembra, quando fala, "um frade franciscano a pregar na Quaresma”).

A coisa ferve quando Inácio, irmão de Jorge, um livre pensador sem cerimônia e oportunista, começa a freqüentar a casa de Bernardo e apaixona-se por Corina. Tipo inconcebível nas representações do teatro popular, por rivalizar com o herói, Inácio é um delator da esperteza das elites rapinantes, da discriminação de classes, da degradação social nas ruas da cidade ("terra de bugres", com meninos de rua, gente suja e descomposta nas ruas, da macaquice dos ricos em relação à Europa, da imitação da França), de modo que pouco zelo demonstra pelos tais valores que o irmão estupidamente defende. Além do que, é um despachado: "o dinheiro devia ser meu (e não do velho Bernardo), porque dinheiro devia ser dado a quem sabe gozá-lo"; do mesmo modo, "mulher bonita só devia ser dada a quem sabe desfrutar e saber desfrutar...

Perspicaz, percebe o amor dissimulado de Jorge por Corina e chega a jogar na cara do irmão: "Esse meu irmão é capaz de andar enrabichado pela mulher do padrinho"). Jorge não o perdoa e pede-lhe que se cale ou retire- 
se... Em vão, porque Inácio acaba seduzindo Corina: um longo beijo num dos compartimentos da casa é testemunhado por Jorge, que por desconfiar, os vivia espionando. Começa aí a exploração impiedosa da estultice moral do pobre afilhado, quando este decide interpelar Inácio pela sedução e o desrespeito ao nome, à família e ao lar de Bernardo. As cenas beiram o ridículo e o grotesco, com Oiticica insistindo em mostrar a loucura de alguém que acredita ser possível defender a honra e a dignidade de uma instituição sem qualquer compromisso em sua origem com a moral a a própria dignidade. "Não posso consentir que a honra de meu padrinho seja infamemente ultrajada, em sua casa, por quem quer que seja".

"Eu ultrajei a honra de ninguém, seu bobo" - responde Inácio, mostrando que Jorge na verdade queria Corina para ele e não se conformava. "Arma-se agora em defensor da honra alheia. Sai-me um bom canalha, você". E adiante: "Quer então impedir o nosso amor? Arranje-se. Quem é besta, peça a Deus que o mate e ao diabo que o carregue". Indignado, o bobo da família chega a interpelar a própria Corina. Primeiro advertindo-a: "A senhora, inexperiente do mundo, não pode, sozinha, resistir às tentações e às maldades dos homens". E depois acusando-a de desonesta e de imoral, de mulher que desrespeita o marido em sua própria casa. "Não preciso de defensores da minha dignidade... Procedo como entendo, bem ou mal, mas como entendo. Nunca precisei de confessores nem guardas de honra. Essa agora..." - lhe diz ela.

Curioso na peça é que Inácio não é a única voz anárquica a espicaçar o bobo da família. O seu foco - mais de inconveniência, de combate rasteiro e frontal ao que lhe parece errado, embora quase nunca ele esteja certo não é o mesmo do libertário clássico, que discerne a ideologia das mazelas e lhes dá a chave filosófica do erro a ser evitado. Numa cena em que discute com Bernardo, que afinal é o marido de sua amante, diz-lhe coisas terríveis com a maior sem-cerimônia: "O senhor é católico fervoroso e monarquista, começa a pregar as suas idéias aqui dentro e não deixa ao rapaz a liberdade de aspirar às idéias republicanas da nossa terra. Qual o resultado? Dá-nos um fanático do papa e da realeza. Sucede que mal a gente assevera que a confissão é uma imoralidade e que Pedro II era um banana, o rapaz se enfuria, manda aos livre pensadores para o inferno e chama os republicanos de bandidos. Está aí o que o senhor faz".

Na verdade, em Pedra que rola não há libertários ortodoxos, mas libertários farsescos. Um outro, mais corrosivo, é Maurício, a segunda voz no aparte às tolices do pobre Jorge, a quem procura desarticular com recursos que vão da advertência à discussão de princípios. Numa conversa ao 
acaso, propõe-lhe que mande o ideal às urtigas: "Vá viver como eu vivo, do melhor modo possível. A vida é um prosaísmo reles e só vivem bem os que nela são prosaicos. Os poetas morrem de fome ou de desespero, como você. Corina é uma mulher como as outras, e o amor, no fim do poema, é a carne do homem que topou na carne da mulher. Deixe de ser bobo, não diga nada a Inácio, nem ao padrinho, finja que não vê e procure outra carne. As carnes femininas custam hoje mais barato".

Tais idéias balizam o ideário da peça e reaparecem a cada cena, matizando o argumento em alguns dos tópicos doutrinários que entre os quais se incluem o da repulsa à "desgraçada humanidade onde a gratidão é uma virtude"; o da desídia dos "homens que deveriam estar organizados de tal modo que todos se considerassem cooperadores da felicidade de cada um"; o da convicção de que "o bem é impossível de ser definido"; o da certeza de que a "bastarda instituição do casamento é uma coisa imoral, é o amor tiranizado..."; o da necessidade de que "o amor, como o trabalho e o pensamento, deve ser livre" ("sem esse desgraçado regime do matrimônio, fruto da iníqua instituição da propriedade particular, Corina não se venderia a Bernardo..."), além de outros que aparecem dispersos em fragmentos de outras falas, como por exemplo: "o difícil é saber o que é a honra"; "essa aspiração (burguesa) do bem... esse desejo de ser bom é uma quimera. Nesta sociedade odiosa em que vivemos, organizados sobre o parasitismo, ninguém pode ser bom"; "fique certo de que nunca se uniformizará o critério da conduta humana, enquanto não forem definidos cientificamente o bem e o mal"; "a regra humana é a cobiça. Ora, meu caro Jorge, suponha-se você nesse maremoto, trepado na jangada da bondade..."; e, por fim, "O mal da sociedade é que o seu fundamento é a concorrência, a luta, e não a harmonia, a cooperação".

Mas a personagem mais viva da peça é justamente Corina. A ambigüidade de seu caráter aproxima-a do enquadramento mais convincente do que deve ser uma personagem teatral, coisa que - convenhamos - não acontece com os outros, todos muito apegados ao esquadro da ideologia. Corina, não. É amante e sabe do risco que está correndo. Tem consciência e coragem suficiente para buscar o direito de amar e ser amada. E depois sabe como ser mulher e explorar os desejos que desperta nos homens. No final da peça, quando Jorge, desvairado, aparando os golpes de Bernardo, arranca-lhe a bengala e passa, ele, a esbordoar Inácio, gritando a todos que nunca deixou de amar Corina, esta - numa reação surpreendente - segura a mão de Bernardo prestes a agredir a Jorge e afeiçoa-se ao tímido pretendente, tomada talvez de remorsos pelo mal que lhe causara. 
CESAR10:

Sals de risitas estelo roopob, peado, porta \& esquerda para un esoritorio, outra ao fundo eaquerdo para uma salets com eacada para o sadar terreo, ao rundo direito janela para a rua.

\section{cogra I}

\section{JORGS $\boldsymbol{z}$ WAUR IC IO}

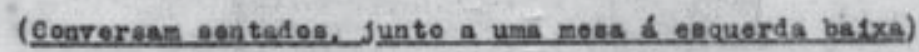

JORGX

Hra de eaperar 1ano. You padrinho 6 forreta eome o diabo... mas aupua que atendesse ao mou primoiro pedido, mormente agora que embol a ou duasntos contos no negoo 10 dae farinhas. I ineoncebirel...

\section{WAUR IC TO}

(Atitude de abatimente moral em tode ato) - Veja 14 se seu jafrinho vae descobrir a rotirata.

\section{JoRGs}

If 0 deecobre... Raramente verifiea e tem abooluta oontianga om mim... MAUR IC TO

I อae Lorpa do Vicente näo veadeu ainda o sitio... ha hma semana... JoRas

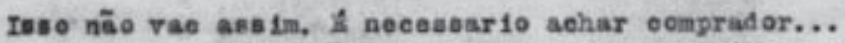
MUN IC IO

Sim,.. ase tenho receio de roca. Por un azar qual quer seu padrinho dé por falta doflif eineo contos. Dans-as com roeê.

\section{JORGS}

I ma1to improrarell

\section{MUER IC TO}

Devezos contar na vida meamo oom o improvarel!

JORGE

Ainda asefm, que importa! Polo roeb havis de ser demitido, deamoraliado, por m oauma do ofneo contob!

\section{WUUR ICIO}

Ifo tenho direito de mete-10 em perigo por minha eauss. Desde que ele recueou, pe remptor lamente, suxil lar-me, ○ seu soto é duplamente perigovo...

\section{JURGa}

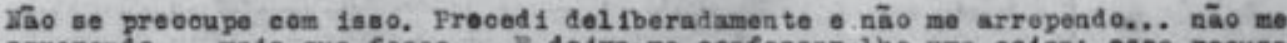

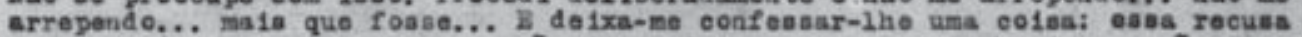
de meu padrinho acendeu en min näo digo od 10, mas uma pontinhs de uversẽo. Sempre

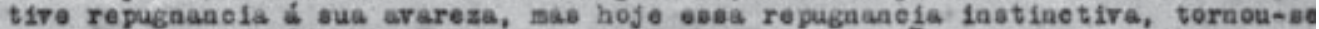
conolente... que diabol Um homen com dous mil oonton, nâo atende ao pedido de einoo, contos foito pela pessba a quem dere, om grande parte, O aumento do gou ca

Fac-simile de uma página do original datilografado da peça Pedra que rola 
No entanto, oprimida e submissa (Bernardo só lhe dirige a palavra para elogios gratuitos e convencionais e para dar ordens - pegue isto, traga aquilo...), sabe responder com altivez, mentindo descaradamente ao marido e inventando uma história de assédio que o pobre Jorge jamais cometeu. Negou mesmo o beijo que dera em Inácio e teve a frieza de sustentar que era perseguida por Jorge. Uma personagem enfim que surpreende, travestindo-se ao mesmo tempo do bem e do mal e por vezes na mesma cena. Com ela, Oiticica logra um outro escopo da sua anarquia: o de viver no palco as mazelas da mediocridade burguesa e as deformações humilhantes a que leva o dinheiro que a patrocina.

Outro irmão distanciado de Inácio é o simpático bêbado Geraldo, filho mimado de uma família conservadora da classe média, que se apaixona pela criada da casa (Paulina), uma pobre moça que os pais (Martins e Gabriela) foram buscar num orfanato distante para criar como filha em Quem os salva, o outro drama de costumes de Oiticica. O tema, que por si só entraria como uma luva no ideário do velho teatro militante da Universidade Popular coligido por Luigi Molinari, vira outra coisa nas mãos de Oiticica. O ritmo lento das cenas, os diálogos irregulares e pesados, o tom excessivo de tragédia miúda cercando a gratuidade dos juízos fazem da peça outra variante tardia do antigo dramalhão romântico, em que os pais são traídos pela independência dos filhos, a pobreza entra como estigma insanável e a capacidade de amar aparece como única saída para arranjar o destino e reparar as injustiças do mundo.

A imagem do bêbado, no entanto, ao amarrar a ambigüidade do argumento, projeta-se como séria ameaça à degradação social, joga com a precariedade de sua própria desgraça e força a nota do humor e da ironia em algumas situações-limite em que faz a defesa do alcoolismo e o contrapõe como resposta à carolice da mãe, às bases morais da família e à autoridade do pai, tudo para sustentar o seu direito de amar Paulina.

Por ser um bêbado "que nunca está bêbado" ou que, quando está, faz chantagem com a mulher amada para atrair-lhe a atenção, Geraldo, paradoxalmente, está sempre raciocinando e exige que os outros também raciocinem. Suas estripulias ganham assim uma inegável dimensão crítica, entre divertida e estabanada, é verdade, mas sempre corrosiva.

A cena em que resolve enfrentar a própria mãe é expressiva. "Modere a linguagem! Modere a linguagem! Exijo mais respeito". Ou "quem lhe mandou ter filhos? Não the encomendei sermão... não lhe pedi para nascer... é que isso lhe deu prazer..." Noutros momentos, a ofensiva é mais radical. Não reconhece a Gabriela o direito de ser mãe. "A senhora é a 
maior culpada... as mães não têm o direito de ter filhos para matá-los... Abomino minha mãe". Ou quando lhe diz que quer casar-se com Paulina para salvá-la da tirania da mãe e grita fora de si, amaldiçoando Gabriela: "A senhora é maldita! maldita!... maldita! ”. A mãe cai desolada e sem força numa cadeira.

O ritmo do humor é quase farsesco nas cenas em que Geraldo responsabiliza o pai, o governo e a sociedade pelo vício da bebida. O pai, por ter trazido o álcool para dentro de casa; o governo por permitir o fabrico e a livre propaganda da bebida; e a sociedade por marginalizar os fracos de espírito que, como ele, vão na conversa e compram a bebida. Aqui a nota de humor é a inclusão dos frades bebedores de licor. "Os bêbados, os frades e os fabricantes", diz Geraldo ao pai, "qual deles é o maior culpado?”.

A tese é que a vontade fraca não tem como resistir aos fortes apelos da propaganda: "Eu acabo entrando... Acha o sr. que eu sou culpado de ter a vontade fraca?", diz cinicamente a Martins. Contra a propaganda intermitente, só pode haver uma saída, diz Geraldo ao pai: "sabendo-me incapaz de resistir à tentação, tomo um alvitre louco: saio pela porta fora, invado a primeira fábrica de bebidas que topar, agarro de um cacete e ponho-me a quebrar filtros, retortas, alambiques e garrafas, a destruir tudo, tudo...". O pai adverte que ele seria preso. "Por certo - responde - no xadrez ou no hospício, culpado pela sociedade, pelo direito de ter reagido ao único modo eficaz contra os miseráveis que exploram minha cabeça fraca... sim contra os miseráveis que depois de me convidarem, incitarem e provocarem a comprar-lhes as bebidas, me apontam a mim e aos outros como viciosos, como perdidos, como ébrios...”.

Para Geraldo, o pai ficará ao lado dos abomináveis sugadores contra “o filho inocente". E aqui o despeito fica ousado e cheio de ironia, sem no entanto deixar de ser chantagem: "Há homens honrados... homens de bem... a quem o sr. aperta a mão e que matam seu filho, o seu Geraldo, a álcool. Envenenam-no lentamente, e o sr. abraça-os e crimina o seu filho, vítima deles”. A alusão rebelde vem um pouco antes: “Ah! meu pai, se todos os que bebem compreendessem... compreendessem e se levantassem conscientemente um dia contra os alcoolizadores dos homens... contra os seus assassinos...”

"Que me diz o sr. - ele emenda - de uma sociedade que pune o homicídio, o ferimento, o simples uso de armas e deixa livre a venda dessas mesmas armas e permite... os anúncios dessas mesmas armas e ensina a manejálas e premiar em concursos aqueles que as manejam bem? Que diz a isso? Não responde? E sou eu que estou bêbado?” 
Nada disso entretanto apaga a dissonância entre a fala e a consciência do bêbado Geraldo. Embriagado, ele alinha todas essas contradições da família, da religião, da sociedade e do Estado burguês. Em estado de lucidez, chantageia o amor de Paulina ao forçar a imagem infeliz do bêbado desamparado que, sem ela, vai se acabar nas sarjetas: "Hei de beber... até cair na lama... na sarjeta... Até morrer um dia inconsciente, odiando a tudo e a todos..."

Ocorre que Paulina o ama e, mesmo reconhecendo a chantagem, decide-se a salvá-lo. Mas Geraldo, apesar de feliz, lamenta que ela não tivesse enfrentado a tirania da família que se sentia degradada pelo casamento de um de seus membros com uma simples criada. Casar-se agora é, para ele, uma forma de derrubar essa tirania, em especial a da mãe, que adotou Paulina como filha para usá-la como empregada.

É então que, munidos dos mais veementes chavões libertários (“desgraçados os inferiores, que põem sua salvação nas mãos dos superiores"; "os inferiores são fracos individualmente, mas centuplicarão suas forças, unidos"), os dois anunciam a Gabriela e Martins que viverão, juntos, a felicidade do amor livre: "não me sacrificarei mais aos preconceitos de burgueses ricos com fumos de nobreza; não thes imolarei o meu coração... só admito para o amor uma lei: o afeto mútuo, o desejo livre dos que se amam". Expunha-se aqui a tese de Oiticica segundo a qual a obediência às normas da família burguesa transformava os filhos em vítimas de uma tirania: brida nos queixos, como a dos burros, os filhos - como declara o próprio Geraldo num aparte aos desatinos da mãe, "são como bons escravos" que obedecem e trabalham sem reagirem à opressão de que são vítimas.

Mas no final as coisas se precipitam. Afonso, o noivo que Gabriela escolhera para a criada, revolta-se com a decisão de Paulina, disposto a "pô-la abaixo de cachorra". Geraldo reage, para desespero de Gabriela, que entra em pânico. Ele e Afonso, este empunhando uma faca, começam a lutar, mas Afonso acaba sendo desarmado e vai embora prometendo vingança.

O final, como no desfecho de Azalan!, é igualmente patético. Os pais enfim concordam com o casamento e Paulina passa de criada a noiva do filho da casa. Mas Geraldo, em estado sóbrio, vai se revelar de uma pobreza inconcebível, como se nada do que dissera antes tivesse a menor razão de ser. $\mathrm{O}$ anticlímax que daí resulta chega a produzir efeitos mais do que grotescos, para não dizer trágicos, se pensarmos na obstinação moral do drama libertário popular. Ao cair do pano, o filho está ajoelhado diante da mãezinha, pedindo-lhe a bênção e as desculpas por tê-la feito sofrer tanto. 
Curiosamente apenas em Não écrime, um ato único em que Oiticica focaliza o amor livre - o grande ideal proposto pelos anarquistas para as relações entre o homem e a mulher - é que a atmosfera da peça parece se aproximar da retórica do teatro militante, impulsionada pela brevidade do texto, pela fluidez de um diálogo cênico sempre ajustado à veemência da recitação, o que deixa o tema muito longe, por exemplo, dos padrões com que foi tratado pela prosa anarquista, em especial nos romances de Fábio Luz e Curvelo de Mendonça.

Em Nãoé crime o argumento se depura e ganha um arranjo que, sem deixar de ser programático, é mais sutil por se valer justamente das rubricas da gestualiadade, decisivas no caso para exposição retórica de uma atitude ostensivamente afrontosa ao convencionalismo do casamento burguês.

Sara e Celso, que se amaram num passado distante, reecontram-se por decisão dela, que soube, pelos jornais, na Europa - para onde a levou o ciúme de um padrasto exasperado - que ele acabara de ser nomeado engenheiro-chefe dos estaleiros de uma companhia de navegação. Ela está mudada, mais madura, mais culta e não menos bonita. Ele, já casado, é agora pai de dois filhos e esconde a mágoa de ter sido abandonado sem ao menos receber uma palavra.

Na primeira cena, ela pede piedade a Celso e quer saber se ele ainda a ama. Ele diz que sim, tão fervorosamente quanto ama a Lina, sua mulher. Sara garante-lhe nada querer dele, além da "certeza de que não me esqueceste nestes cinco anos, de que estou viva em ti". Celso explica-lhe o sofrimento por que passou até o dia em que, chamado pelo pai de Lina para dar à filha algumas aulas técnicas, acabou conhecendo os dons morais superiores e as idéias novas da moça, uma libertária autêntica que o fascinara. Mas jura a Sara que não a esqueceu. "Não quero que te tornes meu amante, que deixes tua mulher e teus filhos. Não, nada disso, seria vileza minha" - ela esclarece.

Lina, que chegava à porta sem que os dois ex-namorados se dessem conta, testemunha parte do diálogo e ouve Celso dizendo a Sara que sua esposa era uma alma das mais nobres: "asseguro-te (...) que se conhecesses de perto Lina, se tratasses com ela, se penetrasses nas profundezas daquela alma rica, esplendente, onde se desabrochavam dia a dia novas surpresas..."

A frase acende o despeito de Sara, que reage com ciúmes: "Ah! como fala dela! Que entusiasmo! Que vim eu fazer aqui!...”. E ele lhe explica, dizendo - e esta é a base do amor livre entre os semelhantes, no entender de Oiticica - que via em Lina a reprodução fiel da alma de Sara: "Não pode 
haver duas naturezas semelhantes, duas criaturas tão igualmente bem prendadas". E conclui: "Eis porque amei Lina, porque loucamente, perdidamente a amo (...) é que amando as duas criaturas, amo um só tipo de mulher... Serei culpado?”.

Segue-se ao galanteio a exacerbação de um conformismo inexplicável que só em parte atenua as descaídas para o melodrama. Sara reconhece os direitos de Lina ("Tua mulher ama-te, não tem culpa do meu destino. Seria abominável que eu viesse a toldar a felicidade dela") e pede a Celso que volte para junto dela, mas ele insiste para que a namorada não regresse à Europa ("Não sairás daqui, promete-me?... eu não consinto") e se exaspera: "Agora quero-te junto e não permito que me fujas (agarra-lhe as mãos) nunca mais. Serei fiel, sempre, a minha mulher, porque Lina é digna disso... e serei fiel a teu amor, porque ele é digno disso".

A encrenca está nesse pé quando Lina, na cena II, se apresenta e diz aos dois que ouviu toda a conversa. Sara desconcerta-se e Celso pede perdão, mas Lina diz que nada há a perdoar, ao contrário: há muito a bendizer, diz ela, comovida com o que ouviu e solidária com os padecimentos de Sara: "Sou testemunha da tortura dessa mulher que te ama e me comovo e choro com ela porque te amo muito e calculo o que seria do meu coração se estivesse na posição dela”.

Sara não consegue entender. Lina insiste em que não está fingindo ("Não faça de mim este juízo hediondo") e chama-a de irmã, "minha grande, verdadeira, consubstancial irmã". O melos se expande e Sara começa a chorar quando Lina procura consolá-la, dizendo-lhe que, amando-a a ela, Sara, Celso ama igualmente a ela própria, Lina: "Não chore mais... seremos muito amigas... - garante. "Quero-lhe o bem de irmã... deixe-me ver nesses lindos olhos o retrato da minha alma".

A ironia não pára aí. O ato se fecha com Lina convidando Sara e Celso a beijarem-se. "Ele não ama nossos corpos - garante a Sara - ama as nossas almas... o corpo nada vale... Meu corpo poderia ter ciúme do seu... Meu espírito não tem...". "Vamos, beijem-se apaixonadamente... - ela insiste - eu suplico, beijem-se com todas as forças da carne e do espírito... quero sentir em mim a vibração desse misterioso amor". Celso e Sara, tímidos, hesitam. Lina os faz abraçarem-se, agarrando as mãos de um nas mãos do outro. E eles se beijam "longa e transubstancialmente". "Seremos muito amigas, muito irmãs, quero vê-la sempre, ter notícias suas... serei a confidente das suas amarguras...", diz Lina a Sara ao final, ao sair com Celso para casa. Sara, perplexa, parece horrorizada ante as promessas da utopia: "Preciso morrer, preciso morrer"... 
Olhando o conjunto dessas peças e personagens, em grande parte concebidas na adversidade do cárcere, talvez caiba perguntar, para concluir, o que poderiam hoje significar para nós. Aparentemente, pouco, se olharmos para a superação das bases conceituais do anarquismo no interior da evolução política do país, especialmente a partir de 1930. Mas podem significar muito quando pensamos que testemunham e fazem parte de um extraordinário empenho intelectual na busca de uma resposta para superar o que Oiticica chamava de teatro de situações e abrir frentes para um teatro de crise naquele momento difícil em que - segundo anota, apoiado em Ibsen - toda a massa política e intelectual sentia a comoção de uma incomparável transformação econômica do mundo. A esse teatro, por mais frágeis que fossem as suas armas, cabia a tarefa de escavar - como fizera o velho Aristófanes nas rachaduras da velha ordem, incorporando com vigor, a inquietação dos oprimidos, a sede de justiça e o ideal da redenção definitiva (19).

\section{Notas}

1 Cf. Candido Jucá Filho. José Oiticica. Paratodos(RJ), 2a. quinzena, jul. 1957.

2 Ver Roberto das Neves. José Oiticica: um anarquista exemplar e uma figura ímpar na história do Brasil. In: José Oiticica - ação direta (prefácio). Rio de Janeiro, Editora Germinal, 1970, p. 23.

3 A tese com que José Oiticica obteve a cátedra de Português do Colégio Pedro II foi publicada no Rio de Janeiro em 1916 com o título de Estudos de Fonologia, área em que foi amplamente reconhecida a sua competência.

4 Teófilo de Andrade. Oiticica e os Aglossói. O Jornal(RJ), 2-3 nov. 1957.

5 Viriato Corrêa. Discurso de homenagem na Academia. Jornal do Comércio (RJ), 7 jul. 1957.

6 Para Álvaro Lins - que destaca em Oiticica a retidão, a assiduidade e a modéstia, (adiou sempre a homenagem que a congregação do Colégio Pedro II queria prestar-lhe por tê-lo eleito professor emérito) - o único traço revolucionário a ressaltar em seu caráter era o otimismo. Ver a respeito Homenagem Póstuma ao professor José Oiticica na Academia Brasileira de Letras - Discursos dos acadêmicos Álvaro Lins, Levi Carneiro e Peregrino Júnior. Jornal do Comércio (RJ), 7 jul. 1957.

7 Osório Borba. Notas sobre uma personalidade. Diário de Notícias(RJ), ago. 1957.

8 Cf. Candido Jucá Filho. José Oiticica, cit. 
9 "No final das provas - conta Roberto das Neves -, reunidos os examinadores para proferirem o veredicto, a maioria deles (...) inclinavam-se para a reprovação. Carlos de Laet, uma das mais notáveis figuras da congregação do Colégio Pedro II, teve então um dos seus gestos nobres. Apesar de católico militante, adversário das idéias anarquistas e um dos mais atacados na tese do examinado, ergueu-se da sua cadeira e protestou: 'Não é possível que num país, como o Brasil, onde raros são os homens de valor, se pretenda reprovar um homem como este, que acaba de demonstrar profundo conhecimento das questões gramaticais e filológicas, apenas porque professa pontos de vista divergentes dos nossos! Que têm a ver o anarquismo e o ateísmo do candidato com o assunto que aqui nos congrega?"”. Ver Roberto das Neves. José Oiticica, um anarquista exemplar e uma figura ímpar na história do Brasil, cit., p. 11.

10 A passagem do jovem Pedro Nava pelo Colégio Pedro II vem narrada nos volumes Balão cativo ( $3^{\text {a }}$ ed., 1977, Rio de Janeiro, José Olympio) Chão de ferro ( $2^{a}$ ed., 1976, Rio de Janeiro, José Olympio).

11 Manuel Bandeira. Oiticica. Jornal do Brasil (RJ), 3 jul. 1957.

12 O próprio Manuel Bandeira escreve no artigo aqui citado: Oiticica "nunca me terá perdoado a minha adesão ao movimento modernista; nunca me terá perdoado ter escrito a 'Estrela da Manhã' ou 'Vou-me embora pra Pasárgada' depois de 'Um sorriso', que ele sabia de cor e musicou, porque - emenda - Oiticica era curioso de tudo e se meteu a estudar harmonia para compor!". Ver Manuel Bandeira. Oiticica, artigo citado no Jornal do Brasil. Sobre a crítica de José Oiticica a Manuel Bandeira, ver o artigo $\mathrm{O}$ preto no branco, publicado no jornal $A c ̧ \tilde{a} o$ Direta (RJ), n. 99.

13 Cf. depoimento de Alberto da Costa e Silva a John W. Foster Dulles, recolhido em Anarquistas e Comunistas no Brasil (1900-1935). Rio de Janeiro, Nova Fronteira, 1977.

14 John W. Foster Dulles. O movimento de greve anarquista - Planos para derrubar o governo. In: Anarquistas e Comunistas no Brasil, cit., p. 68.

15 As citações entre parênteses acompanham a versão publicada das notas manuscritas tais como aparecem em José Oiticica, Curso de literatura (coligido e revisto por Roberto das Neves). Rio de Janeiro, Editora Germinal, 1960.

16 Ver Lily Litvak. Musa libertaria - arte, literatura y vida social del anarquismo español (1880-1913). Barcelona, Antoni Bosch, 1981, p. 213-214.

17 A personagem-espelho, segundo Eva Golluscio de Montoya, é aquela que sofre no palco o processo de aprendizagem necessária que a peça quer transferir para o espectador militante, levando-o à libertação intelectual e moral. Cf. Pactos de representación en un teatro militante: el problema del destinatário. Washington, jun. 1990, p. 9 [mimeo]. 
18 Sobre a estrutura do teatro popular libertário ver, além do já citado texto de Eva Golluscio de Montoya, o estudo Ideología libertaria en escenarios rioplatenses, de Nora Maziotti. Espacios (Buenos Aires), v. IV, n. 6-7, p. 99-108, abr. 1990.

19 Cf. José Oiticica. O teatro de hoje. Rio de Janeiro, s/d, p. 9 [mimeo].

Antonio Arnoni Prado é professor do Departamento de Teoria Literária do Instituto de Estudos da Linguagem da Unicamp. É autor de vários livros, entre eles 1922 - Itinerário de uma falsa vanguarda (1983), Contos anarquistas (1985) e Libertários no Brasil (1986). 